Volume 12

$12-2018$

\title{
Guest Editorial: Justice for and Prevention of Genocide
}

Melanie O'Brien

University of Western Australia

Follow this and additional works at: https://digitalcommons.usf.edu/gsp

\section{Recommended Citation}

O'Brien, Melanie (2018) "Guest Editorial: Justice for and Prevention of Genocide," Genocide Studies and Prevention: An International Journal: Vol. 12: Iss. 3: 2-3.

DOI:

https://doi.org/10.5038/1911-9933.12.3.1650

Available at: https://digitalcommons.usf.edu/gsp/vol12/iss3/4

This Editorial is brought to you for free and open access by the Open Access Journals at Digital Commons @ University of South Florida. It has been accepted for inclusion in Genocide Studies and Prevention: An International Journal by an authorized editor of Digital Commons @ University of South Florida. For more information, please contact digitalcommons@usf.edu. 


\section{Guest Editorial: Justice for and Prevention of Genocide}

In 2017, the International Association of Genocide Scholars (IAGS) conference was held at the University of Queensland (UQ), Brisbane, Australia. Hosting by the UQ Law School and the AsiaPacific Centre for the Responsibility to Protect (R2P Centre), the theme was Justice and Prevention of Genocide. The conference was a resounding success, attending by almost 200 scholars from around the world. Papers were delivered on topics ranging from the Armenian Genocide to the Indonesian atrocities of 1965, climate change, the Extraordinary Chambers in the Courts of Cambodia (ECCC), and Indigenous genocides. The latter topic was particularly relevant given the host country, Australia, and its history as a colonised land, leading to massacres of local Aboriginal populations, removal of Aboriginal children from their families, ${ }^{1}$ and ongoing inequalities between Aboriginal and other populations today. One of the keynote speakers was a local Aboriginal elder, Lilla Watson, who opened the conference at the Welcome Event. Her keynote was particularly poignant and moving, detailing the impact of colonisation on Aboriginal people, and the personal connection for her with these atrocities.

Three of the other keynote speeches are included in this special issue. Alex Bellamy, Director of the R2P Centre, and foremost expert on R2P, spoke on 'Holding Back the Tide? Human Protection and Genocide Prevention in our More Violent World', where atrocity prevention is key in a time of global conflict. William Smith, the Deputy Co-Prosecutor of the ECCC, spoke about the different types of evidence required to prove atrocities at the ECCC, with a particular focus on the importance of the work of scholars in the field and the role they played in the trial. Robert Cribb talked about the limits of historical guilt over atrocities, with specific reference to the case of Japan in WWII and its post-war relations with the West.

A screening of the film 'Denial' at IAGS2017 was particularly relevant and timely, given that, only two months before the conference, Holocaust denial flyers were found on the campus of UQ, as well as other Australian universities. ${ }^{2}$ Included in this special issue are the three talks from panellists Henry Theriault, Kirril Shields and Ted Nanicelli, who analysed different aspects of the film and the continuing problem of genocide denial.

Drawing from the theme of IAGS2017, this special issue contains five articles focused on the theme of justice for and prevention of genocide. Judith Rafferty's empirical research in Rwanda examines the needs and desires of women victims of sexual violence during the 1994 genocide, for whom 'justice' takes many different perspectives. Rebecca Gidley and Matthew Turner's piece looks at the role of historians as expert witnesses in trials for international crimes, comparing West Germany Holocaust trials with those of the ECCC and the Bangladesh Tribunal, and the challenges that are presented from this very specific category of expert witness. Caroline Bennett's interviews with Cambodians have explored how the Cambodians view the concept of 'karma' within the justice and reconciliation landscape in post-Khmer Rouge Cambodia. Katherine Southwick touches upon one of the most current genocidal cases- the Rohingya- presenting a sociology of law perspective as to why the international community has failed to act to prevent the genocide in Myanmar. Finally, Bjoern Schiffbauer considers the concept of 'naming and shaming' as a method of genocide prevention, and where the challenges lie in its effectiveness as a prevention option under the Genocide Convention. Thus, there is a balance in the articles between the two main concepts of 'justice' and 'prevention'; two equally important concepts, and inherently connected to each other: justice steps in where prevention fails, justice is rarely needed where prevention succeeds, and justice itself is a form of prevention.

As a human rights and international criminal lawyer, a majority of my work is focused on prosecution of perpetrators of atrocities and human rights violations. That is, it is focused on justice.

\footnotetext{
${ }^{1}$ See "Bringing Them Home", a report (1997) and storytelling project of the Australian Human Rights Commission, accessed November 7, 2018, https://bth.humanrights.gov.au/.

${ }^{2}$ Rachel Clun, "Holocaust denial flyers distributed around University of Queensland widely condemned", Brisbane Times, May 3, 2017, accessed November 7, 2018, https://www.brisbanetimes.com.au/national/queensland/holocaust-denialflyers-distributed-around-universtity-of-queensland-widely-condemned-20170503-gvy3tz.html.
} 
However, I would very happily find myself without a job should prevention measures all succeed. Sadly, this is unlikely to be the case any time in the near future. Thus, it is essential that we all work together, in both fields, prevention and justice, to ensure that, where possible, atrocities are prevented, or otherwise, that perpetrators of these atrocities are held accountable and impunity is no longer routine. At domestic and international level, actions of every individual make a difference, and we should not despair, but rather only increase our passion and purpose to create a world of tolerance, inclusion, kindness, fairness and dignity. Such actions start at home in our everyday activities and behaviour, and flow to the very pinnacle of government and international leadership. Remember that to create a society where social justice is a primary underlying principle, we need to actively support democracy and rule of law; we need to play our role, through our scholarship and teaching, but also through participating in democratic processes such as voting, protests and interaction with our government representatives. As genocide scholars, we are privileged to have an education and a profession that allows to engage with current affairs and intellectual debate. We need to ensure that we take this to our government representatives, pressuring them not only on local issues, such as police targeting of racial minorities, but also international matters such as imposing bi-lateral sanctions on perpetrators of atrocities or sponsoring a UN resolution advocating action to protect a targeted civilian population. After all, the UN can act, but it is only the sum of its member states- which are only the sum of their populations. And those populations include us.

Melanie O'Brien 